\title{
Research on Cultivation Model Reform of College Students Innovation and Entrepreneurship based on "Internet plus"
}

\author{
Jinguang Du, Wenbin He*, Wuyi Ming, Yang Cao \\ School of Mechanical and Electrical Engineering \\ Zhengzhou University of Light Industry \\ Zhengzhou, China \\ dujinguang@zzuli.edu.cn; *hwb@zzuli.edu.cn; mwy@163.com; caoyang8786@126.com
}

\begin{abstract}
To explore the influence of "Internet plus" on innovation and entrepreneurship of college students and how to use the Internet to expand students' innovative entrepreneurial ability, this paper gives an analytical investigation on cultivation model reform of college students innovation and entrepreneurship based on the "Internet plus". Through analyzing the characteristics of the model of talent cultivation of college students' innovation and entrepreneurship education mode, research and practice on the cultivation of innovative entrepreneurial talent, it is helpful to strengthen the cultivation of college students' innovation ability, improve college students' innovative entrepreneurial practice platform, and improve the innovation and entrepreneurship guidance teachers. So we can break the traditional teaching model based on "classroom as the center, teacher as the center and teaching materials as the center". The traditional subject curriculum model based on the integrity of the knowledge selection courses content can be also broken. The modular curriculum system under the guidance of the system engineering thought can be set up.
\end{abstract}

Keywords-cultivation; model; reform; innovation; entrepreneurship

\section{INTRODUCTION}

It is an important task for college students to innovate and entrepreneur under the national encourage and advance, cultivating new talents with innovative spirit and entrepreneurial goal is also an important duty and mission of all kinds of colleges and universities in education. For colleges and universities, on one hand, we should make full use of policies to encourage students to start their own businesses. On the other hand, in order to substantially strengthen the input and implementation of entrepreneurship education, it is particularly important for colleges and universities to reform the training mode of innovative and entrepreneurial education [1-2]. At the same time, China has entered the rapid growth age of Internet development. The growth of the number of Internet users is rapid. The use of mobile internet is wide. In the three session of the twelve National People's Congress, the premier Li Keqiang firstly proposed the "Internet plus" action plan in the government work report. It's not just this, represented by the mobile Internet of the students mobile

The general topic of 13th five-year plan for education science of Henan province" Teaching reform and experience of mechanical specialties for Henan province basis of engineering education professional certification" ((2017)-JKGHYB-0055) and the tenth university-level education and teaching reform project of Zhengzhou University of Light Industry.
Internet business competition, and the traditional Internet Baidu University search marketing contest and other use of modern information technology to develop students' innovative business information services platform, and so a variety of independent business sites continue to emerge. In addition, through the college graduate's entrepreneurship competition, "Innovation Cup" (the original "challenge cup") college students' entrepreneurship competition in colleges and universities, "Chinese" Wing "youth entrepreneurial innovation contest, college teachers teaching entrepreneurship curriculum teaching competition, in order to promote learning, promote the teaching way, and lead the college students business plan [3-4].

However, the lack of innovation and entrepreneurship talent training in colleges and universities, not only restricts the deepening of innovation and entrepreneurship in our country, but it is the factor that causes the main gap between China higher education and the developed countries' in the world. Mainly shows in these aspects: innovative entrepreneurial education philosophy lag, and professional education is not tight, and out of the practice; Lack of the consciousness and ability, teachers carry out innovation and entrepreneurship education, and the teaching methods and ways are single, and the pertinence and effectiveness are not strong; Lack of practice platform, guidance and assistance are not in place, innovation and entrepreneurship education system need to be improved.

Under the background of the Internet, college students face a variety of opportunities and challenges. At present, owing to the innovation and entrepreneurship education of college students in China is gradually developing. There is still a gap between theory and practice. The students' ability and the market's demand is not match. There are three low phenomena of low rate of entrepreneurship, low success rate and low technical content in college students' innovative undertaking. Therefore, in order to further promote public entrepreneurship, innovation, in-depth implementation of the general office of the State Council issued "on deepening the reform of the institutions of higher learning innovation entrepreneurship education implementation Opinions" is necessary to further study the "Internet plus" from the perspective of students' 
innovation ability, deeply reform the training mode of innovative talents [5].

At present, the mode of personnel training in colleges and universities in China is too "homogeneous" on the one hand, just like the same product produced under a standard line, lacking of the ability of innovation and entrepreneurship and the social adaptation. It is difficult to adapt to modern science and technology development and economic development needs. On the other hand, it is too "simple", the lack of greater flexibility. It is difficult to meet the diverse needs of contemporary college students' personality development, and is contrary to the social advocacy of "lifelong learning" educational philosophy. This requires colleges and universities to establish the concept of quality education as the core of innovation and entrepreneurship education, to provide students with disciplines of professional cross-learning platform and channels, and actively implement the heuristic and discussion of teaching, to stimulate students to think independently and find problems, the ability to analyze problems and solve problems, the ability to effectively improve the quality of teaching, to enable students to experience, understand the process of knowledge generation and development, training students' scientific spirit and innovative thinking habits.

To sum up, it is imperative to construct individualized and innovative talents training mode in colleges and universities. Therefore, as the background, this paper aims to regard "Internet plus", through analyzing the characteristics of the model of talent cultivation of college students' innovation and entrepreneurship education mode, research and practice on the cultivation of innovative entrepreneurial talent, in order to strengthen the cultivation of college students' innovation ability and improve college students' innovative entrepreneurial practice platform, improve the innovation and entrepreneurship guidance teachers, further study on college students' innovation system reform, and promote our applied talents training mode reform to lay a good foundation.

\section{RESEARCH STRATEGY}

In view of the above background, research of the innovation and entrepreneurship training mode and training program of college students' will be studied from the following three aspects.

\section{A. Cultivation Mode Construction of Innovative Entrepreneurship Talents}

At present, China's high education system is a multi-level and multi-type complex system, which determines the administrative level of innovation and entrepreneurship in China. Only different innovative entrepreneurial training modes of talents are identified aiming at different levels and types of colleges and universities, and it can facilitate the formation of diverse high-quality innovative entrepreneurial talents. The complete professional construction information platform brings convenience to the educates. At the same time, it also solves the employment problem of the professional talents [6].
Using the technology of the Internet to rationally allocate the effective resources of traditional industries can build a

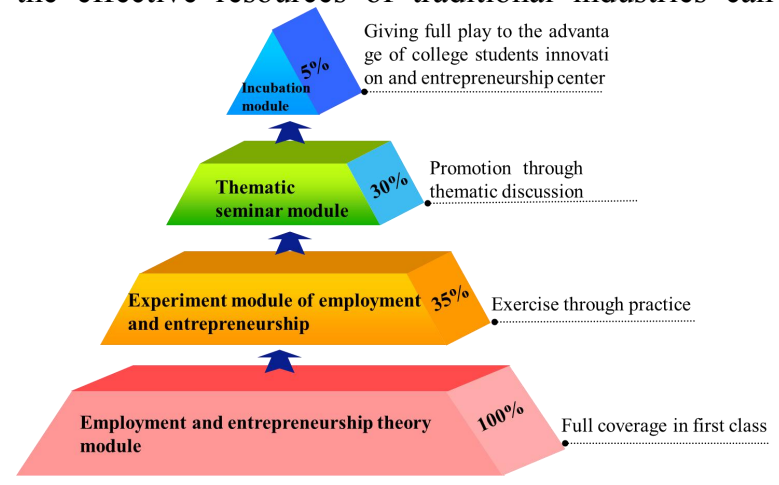

Fig. 1. Multicultural curriculum setting

variety of innovative entrepreneurial talents training mode. Colleges and universities can adopt the following principles: First, cultivate the innovative entrepreneurial thinking. Many students are lack of ability to flexibly apply knowledge, and innovative consciousness, so students should be guided correctly in the process of innovation and entrepreneurship training. More courses related to innovation and entrepreneurship should be opened and the research method of "combine theory with practice" should be further strengthened.

The second is multicultural professional training mode.Fig.1 gives the multicultural curriculum setting. Students can't just limit you to teach some a major. After grasped basic professional knowledge, they are more involved in other disciplines. There are some cross-specialty optional courses offered by the college, which meets the demand of professional compound talents for Internet plus. Thirdly, students should study sth. in order to apply it. That is, students apply professional knowledge to practice to improve their learning interest and efficiency. Internet plus is of effectiveness. On the basis of combining traditional industry, innovation can embody its existence value.

\section{B. Reform of Teaching Curriculum System Based on the Internet}

Fig. 2 shows a learning pyramid which also represents a cultivation mode. Relying on the academic committee of college students, regular lectures, discussions, sharing, and entrepreneurship salon activities will be carried out to strengthen classroom teaching and consolidate innovation and entrepreneurship foundation and exchange entrepreneurial information. Construction institute of innovation and entrepreneurship education website and the majority of teachers and students online exchange platform can improve the atmosphere to create innovative business. In the environment of "internet plus", regarding micro-classdiscussion -practice as the key in teaching activities.

Fig. 3 shows the micro-course schema. the factors of training objectives, teaching procedure, curriculum systems, teaching content, curriculum systems are taken into overall consideration. The development of the modular teaching modules based on project objectives is developed by the various themes. The study is aimed to promote the 
establishment of the innovative entrepreneurship curriculum system based on the module teaching unit.

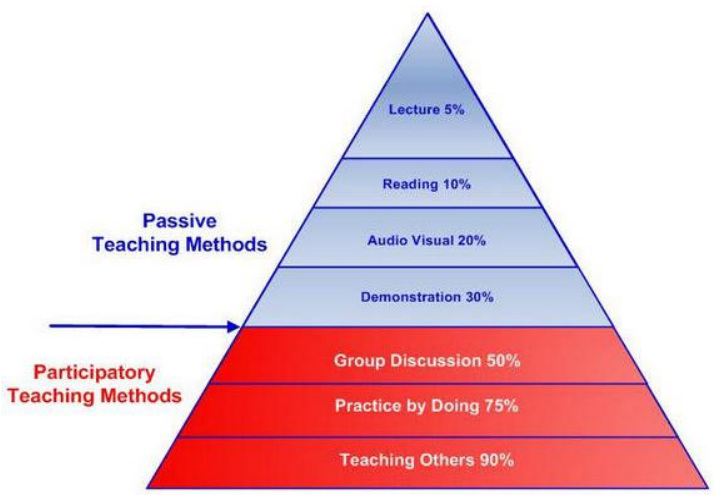

Fig. 2. Learning pyramid

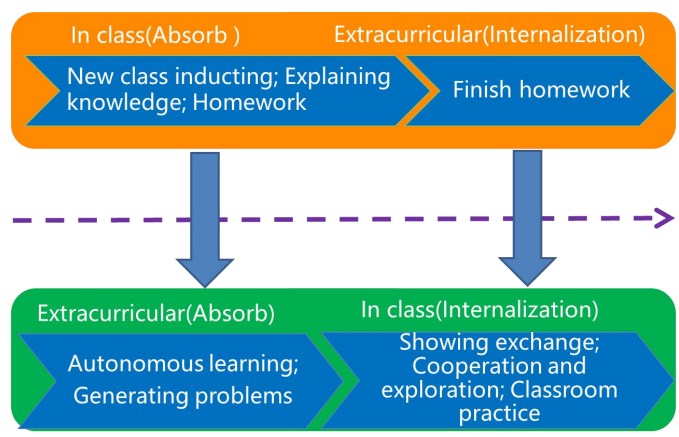

Fig. 3. Micro-course schema

In the environment of "internet plus", regarding microclass-discussion-practice as the key in teaching activities. The factors of training objectives, teaching procedure, curriculum systems, teaching content, curriculum systems are taken into overall consideration. The development of the modular teaching modules based on project objectives is developed by the various themes. To carry out the project tasks to determine - work plan - project organization - check and evaluation summary rating file "implementation method, that is, teaching unit to organize and implement in an iterative way come to meet the learning needs of different levels so as to cultivate students' autonomous learning ability and improve students' learning agility[7].

Through information communication technology, Internet platforms, and the education method reform servicing to the enterprise, we can locate the cultivation conception of "Knowledge+Ability+Quality", explore the comprehensive talent training mechanism of education innovation and entrepreneurship, and build a professional team of teachers. And then, "Internet plus"education mode and building network teaching platform of "Internet plus" course can be innovated, which cultivate the students' self-learning ability of "Internet plus" learning. Making flipped classroom become reality can provide countermeasures for innovation and entrepreneurship training in colleges and universities. The relevant platforms can be used to enable students to preview the preview in advance[8].

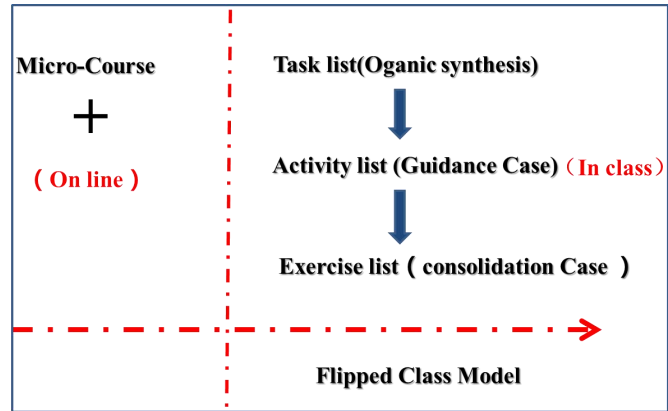

Fig. 4. What the class relies on "Flipping"?

In the environment of flipped classroom, the factors of teaching objectives, teaching procedure, teaching content, hard and easy degreen of knowledge point are taken into overall consideration. Fig.4 gives "What the class relies on "Flipping"?". By reorganizing the course system, what needs to be done using traditional teaching methods, what needs to be done using fipped teaching which takes microlecture as the carrier, and what needs to be done by letting students have an in-depth discussionis are identified.

At last, taking the combination of traditional teaching and micro-class-discussion-practice as the key, the whole course is design into blending learning. In the process of blending learning, there is a need for the part of flipped teaching taking micro lecture as a carrier and the part that needs to be discussed in depth. By restructuring and combining relevant knowledge point, integrating the theory teaching part, the relevant parts instead as a special topic are made into short video [9].

\section{Entrepreneurial Practice and the Development of Cloud Platform Based on the Internet plus}

Through the university students' Pioneer Park, skill training base and school enterprise cooperation, the students' real innovation and entrepreneurship platform will be created. Students are able to gain project experience by using the database and internet technologies to search for multidisciplinary, academic, cutting-edge knowledge, online exercises and communication based on the open, design and comprehensive project.

Relying on the academic committee of university students helps to carry out the activities of "academic auditorium", strengthen the construction of academic atmosphere and guide students to broaden their horizons. By supporting the innovation communities of students and increasing SRT investment encourage students to participate in scientific research project and guide students into the second classroom. The atmosphere of innovation and entrepreneurship of the whole hospital is strengthened by combining professional features with research projects. The innovation and entrepreneurship project team is established based on disciplines and specialties by implementing interdisciplinary and complementary grades and carry out training activities of innovation and entrepreneurship and cultivate team cooperation and management ability.

Fig.5 shows the diagram of innovation and entrepreneurship practice platform. By integrating practical 
teaching resources and with the help of modern information technology, the service for hardware cloud, software cloud, resource cloud and teaching cloud is realized. Various forms of resource sharing services can be carried out by online, offline and mobile terminal. The limitation of practice teaching space and practice teaching resources is of practice teaching space and practice teaching resources are broken through.

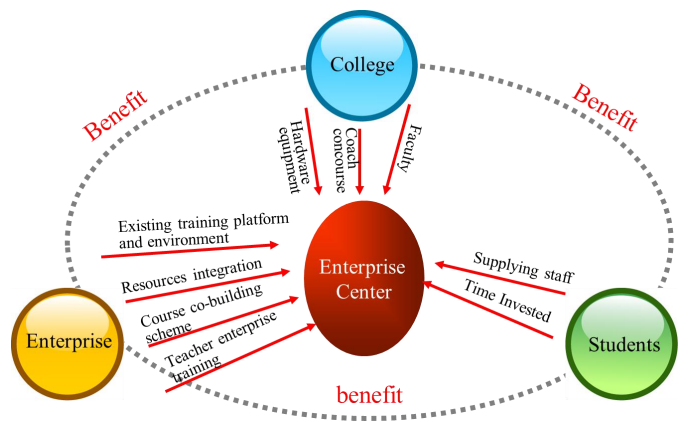

Fig. 5. Innovation and entrepreneurship practice platform

\section{RESEARCH OBJECTIVES AND THE KEY PROBLEMS}

\section{A. Research Objectives}

Through the integration of teachers, innovation and entrepreneurial team, the university students' entrepreneurship education system is established; the entrepreneurial awareness is cultivated; the entrepreneurial thinking is trained; the entrepreneurial practice is organized; and the entrepreneurial effect is evaluated. It can provide a comprehensive service platform for college students' innovation and entrepreneurship, and perfect the existing curriculum system, teaching model, teaching content and teaching methods, furtherly and actively explore the students' entrepreneurial talent training mode and deliver with modern consciousness and the spirit of the age of the creative and entrepreneurial talents for society in order to achieve the higher levels of employment guidance in the "Internet plus" era.

\section{B. The Key Problems}

\section{1) The Design and Evaluation Questions of the Teaching} System of Innovative Entrepreneurship Talents

On one hand, innovation and entrepreneurship training not only emphasizes the theory of teaching but also it should be closely integrated with case analysis and software tools. At last, the improvement of professional skills should be carried out. On the other hand, as the applied undergraduate college students not only master the software operation but also grasps the deep knowledge based on the internet. Software is just a tool, but the entrepreneurship and innovation personnel training teaching is complicated system engineering. How to establish operable and scalability of the curriculum system is a key problem of this topic.

\section{2) Cultivation of Creative Thinking Based on the "Internet} Plus"

As a modern means of information technology, the internet has been widely used in the construction of digital resources learning platform, and its status has gradually changed from "tools" to "environment." Its technology helps teaching, meanwhile, it is gradually integrated into the teaching deeply. How to carry out the training of internet technology and reorganize the teaching resources better and develop a variety of virtual training teaching platforms and effectively eliminate the time and space constraints of skills teaching is also a key issue of this subject.

\section{SUMMARY}

1)Break the traditional teaching model based on "classroom as the center, teacher as the center and teaching materials as the center" in order to translate to the curriculum system surrounding college students' innovation and system surrounding college students' innovation and entrepreneurship ability.

2) Break the traditional subject curriculum model based on the integrity of the knowledge selection courses content and set up the modular curriculum system under the guidance of the system engineering thought.

3) "Internet plus" is as the carrier to realize working and learning combination. Construct the teaching situation according to the project's needs. Let the students construct the relevant theoretical knowledge in the learning process and develop the cooperative learning ability.

\section{REFERENCES}

[1] M.K. Shen, Z.R. Wen, and D.G. Zhan. "Research and practice of the practical teaching system of entrepreneurship education in higher vocational colleges," Journal of Innovation and Enterprise Education. vol. 3, pp. 75-78, June 2012. (In Chinese)

[2] M. Xu. "Mode selection and path optimization of college students' entrepreneurship in "internet plus" era," Journal of China Youth College for Political Sciences. vol. 5, pp. 49-55, June 2015. (In Chinese)

[3] X.W. Li. "Research of the practical teaching system of entrepreneurship education in higher vocational colleges," Continue Education Research. vol. 9, pp. 49-55, September 2012. (In Chinese)

[4] L. Chen. "Mode Explore of College Students' Entrepreneurship in "internet plus" era," Journal of Seeking Knowledge Guide. vol. 3, pp. 35-36, Mar 2016. (In Chinese)

[5] Z.R. Xu. Analysis of the Innovation and Opportunity of Traditional Industry in "internet plus" era," China Internet. vol. 5, pp. 1-5, May 2015. (In Chinese)

[6] Q.S. Gao. "Mode selection and path optimization of college students' entrepreneurship in "internet plus" era," Academic Forum. vol. 30, pp. 159-161, 2016. (In Chinese)

[7] W. Cai. "Educational reform in "internet plus" era," China Education Daily. vol. 4, April 2015. (In Chinese)

[8] C.J. Di, M. Qiang, and Z.L. Wang. "Research of the innovation and Entrepreneurship Talent Training Mode of higher education based on the "internet plus"," Journal of Chongqing University of Science and Technology(Social Sciences Edition). vol. 10, pp. 109-112, October 2016. (In Chinese)

[9] C.Y. Peng, X.H. Dai, and X.Q. Liu. "Construction of public experiential teaching platform based on the cloud computing," Experimental Technology and Management. vol. 32, pp. 193-196, April 2015. (In Chinese) 